\title{
Suicide in the elderly: approach to social determinants of health in the Dahlgren and Whitehead model
}

\author{
Suicídio em idosos: abordagem dos determinantes sociais da saúde no modelo de Dahlgren e Whitehead \\ Suicidio en ancianos: abordaje de los determinantes sociales de la salud en el modelo de Dahlgren y Whitehead
}

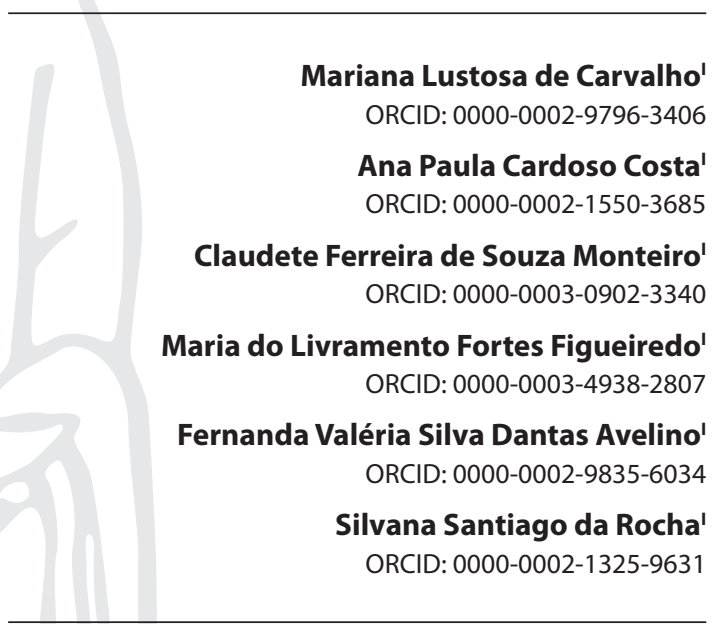

'Universidade Federal do Piauí. Teresina, Piauí, Brazil.

How to cite this article: Carvalho ML, Costa APC, Monteiro CFS, Figueiredo MLF, Avelino FVSD, Rocha SS. Suicide in elderly: approach to social determinants of health in the Dahlgren and Whitehead model. Rev Bras Enferm. 2020;73(Suppl 3):e20200332. doi: http://dx.doi.org/10.1590/0034-7167-2020-0332

\section{Corresponding author: \\ Mariana Lustosa de Carvalho \\ E-mail: marianalustosacarvalho@gmail.com}

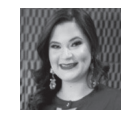

EDITOR IN CHIEF: Antonio José de Almeida Filho ASSOCIATE EDITOR: Hugo Fernandes

Submission: 06-02-2020

Approval: 08-13-2020

\begin{abstract}
Objective: Identify in literature the social determinants of health related to suicide in the elderly, according to the model proposed by Dahlgren and Whitehead. Method: Integrative review of articles indexed in the databases BDENF, CINAHL, LILACS, and MEDLINE, with the following main descriptors: aged, suicide, social determinants of health, and risk factors. Primary studies were included which addressed social determinants of health and suicide in the elderly. Results: From the 19 articles analyzed, three categories emerged: proximal social determinants of health (male gender, mental disorders, physical illnesses, white race, 70-74 years old); intermediate social determinants of health (substance abuse, use of alcohol or psychotropic drugs, marital status, marital, social, and family problems, violence, previous suicide attempt, history of admission to psychiatric service); and distal social determinants of health (schooling, economic issues, sanitation, stressful events). Conclusion: Proximal determinants have more effects on suicide. Intermediate determinants are composed mainly of changeable factors. Distal determinants showed lesser associations.
\end{abstract}

Descriptors: Suicide; Elderly; Social Determinants of Health; Risk Factors; Mental Health.

\section{RESUMO}

Objetivo: Identificar na literatura os determinantes sociais da saúde associados ao suicídio em idosos, segundo modelo proposto por Dahlgren e Whitehead. Método: Revisão integrativa de artigos indexados nas bases BDENF, CINAHL, LILACS e MEDLINE, com descritores principais: aged, suicide, social determinants of health, risk factors. Foram incluídos estudos primários, que abordaram determinantes sociais da saúde e suicídio em idosos. Resultados: Dos 19 artigos analisados, emergiram três categorias: determinantes sociais da saúde proximais (sexo masculino, transtornos mentais, doenças físicas, raça branca, faixa etária de 70 a 74 anos); intermediários (abuso de substâncias, uso de álcool ou de medicamentos psicotrópicos, estado civil, problemas conjugais, sociais e familiares, violência, tentativa de suicídio anterior, histórico de admissão em serviço psiquiátrico); distais (escolaridade, questões econômicas, saneamento, eventos estressantes). Conclusão: Determinantes proximais exercem mais efeitos sobre o suicídio. Determinantes intermediários são compostos principalmente por fatores modificáveis. Determinantes distais apresentaram menores associações.

Descritores: Suicídio; Idoso; Determinantes Sociais da Saúde; Fatores de Risco; Saúde Mental.

\section{RESUMEN}

Objetivo: Identificar en la literatura los determinantes sociales de la salud relacionados al suicidio de ancianos, según modelo de Dahlgren y Whitehead. Método: Revisión integrativa de artículos indexados en las bases BDENF, CINAHL, LILACS y MEDLINE, con descriptores principales: aged, suicide, social determinants of health, risk factors. Incluyeron estudios primarios, que abordaron determinantes sociales de la salud y suicidio de ancianos. Resultados: Los 19 artículos analizados, emergieron tres categorías: determinantes sociales de la salud proximales (sexo masculino, trastornos mentales, enfermedades físicas, raza blanca, franja etaria de 70 a 74 años); intermediarios (abuso de sustancias, uso de alcohol o de medicamentos psicotrópicos, estado civil, problemas conyugales, sociales y familiares, violencia, tentativa de suicidio anterior, histórico de admisión en servicio psiquiátrico); distales (escolaridad, cuestiones económicas, saneamiento, eventos estresantes). Conclusión: Los determinantes proximales ejercen más efectos sobre el suicidio, los intermediarios son compuestos principalmente por factores cambiables y los distales presentaron menores relaciones.

Descriptores: Suicidio; Anciano; Determinantes Sociales de la Salud; Factores de Riesgo; Salud Mental. 


\section{INTRODUCTION}

Aging means going through a stage of human development that encompasses the interaction of biological, psychological, and social aspects, particular to the life of elderly people. The loss of autonomy as well as the appearance of pathologies and physical restrictions generate feelings of dissatisfaction and uselessness, leading to a psychological discomfort that implies a reduction in the quality of life. These changes in the course of aging are risk factors for suicide ${ }^{(1)}$.

This is a complex phenomenon, influenced by multiple variables, which causes intentionally self-inflicted death ${ }^{(2)}$. It is estimated that each year 800 thousand people commit suicide - and age is a strong aspect of its occurrence. Higher mortality rates have been observed among individuals aged 70 or older compared to younger people ${ }^{(3)}$.

There is no singular motivation for this act. I may be a result of an interaction of factors. Unlike what occurs in other age groups, in the elderly it is observed that suicidal behavior has manifestations that are difficult to verify. However, one thing is certain: methods are more lethal and passive suicide is frequent, for instance when refusing food ${ }^{(4)}$.

This scenario points to a need of understanding the determinants for the occurrence of suicide in the elderly, especially considering that those are commonly related to a wide network of social and cultural aspects of the individuals themselves and their families ${ }^{(1,5)}$.

The social determinants of health (SDH) are the circumstances in which individuals are born, develop, live, work, and age. They are outlined by social, economic, cultural, psychological, and behavioral arrangements, which have an influence on the recurrence of health disorders and risk conditions in the population. This set of elements must be organized and explored, in order to define the singularity of subjects and the particularity of phenomenons ${ }^{(4,6)}$.

Identifying the SDHs that are related to suicidal acts among the elderly has implications for the unique context of each individual, based on their visibility, especially by health professionals. With this understanding, the determinants will be able to be tracked and monitored in the scope of assistance. For the social panorama, the understanding of the SDHs involved in each phenomenon and by age group can reduce the disparity between groups and greatly strengthen equity in health.

\section{OBJECTIVE}

To identify in literature the social determinants of health related to suicide in the elderly according to the model proposed by Dahlgren and Whitehead.

\section{METHODS}

This is an integrative literature review. Its construction was carried out following the steps proposed by Ganong ${ }^{(7)}$ : formulation of the problem and elaboration of the guiding question; selection of articles; categorization of studies; analysis of the data obtained; discussion and interpretation of results; presentation of the integrative review and synthesis of knowledge.

Initially, it was verified the available knowledge about the relationship between the social determinants of health and the occurrence of suicide in the elderly. A research question was therefore elaborated according to the PICo strategy, in which "P" corresponds to Participants, "I" to phenomenon of Interest and "Co" to Context of the study ${ }^{(8)}$. The following question came out: what are the social determinants of health associated with the occurrence of suicide in the elderly population?

The controlled (CD) and uncontrolled (UCD) descriptors were then selected. To do so, it were consulted Health Sciences Descriptors (DeCS in Portuguese), Medical Subject Headings (MeSH) and List of Headings of CINAHL Information Systems, which are presented in Chart 1.

The bases selected for this search were: Nursing Database (BDENF), Index to Nursing and Allied Health Literature (CINAHL), Latin American and Caribbean Literature in Health Sciences (LILACS) and Medical Literature Analysis and Retrieval System Online (MEDLINE), via PubMed. The search took place between June and August 2019, by two researchers, simultaneously, in the aforementioned databases, accessed through the Periodical Portal of the Coordination for the Improvement of Higher Education Personnel (CAPES in Portuguese), in an area with Internet Protocol (IP) recognized.

Chart 1 - Stratification of the research question following the PICo strategy, Teresina, Piauí, Brazil, 2019

\begin{tabular}{|c|c|c|c|}
\hline Description & Components & Type & Descriptors \\
\hline \multirow{3}{*}{$\begin{array}{l}\text { Participants } \\
\text { (P) }\end{array}$} & \multirow{3}{*}{ Elderly People } & DeCS & Elderly \\
\hline & & $\mathrm{MeSH}$ & Aged \\
\hline & & CINAHL titles & Aged \\
\hline \multirow{3}{*}{$\begin{array}{l}\text { Phenomenon of } \\
\text { interest } \\
\text { (I) }\end{array}$} & \multirow{3}{*}{$\begin{array}{l}\text { Social } \\
\text { determinants } \\
\text { of health }\end{array}$} & DeCS & Suicide \\
\hline & & $\mathrm{MeSH}$ & Suicide \\
\hline & & CINAHL titles & Suicide \\
\hline \multirow{3}{*}{$\begin{array}{l}\text { Context of the } \\
\text { study } \\
\text { Co }\end{array}$} & \multirow{3}{*}{ Suicide } & $\mathrm{DeCS}$ & $\begin{array}{l}\text { Social determinants of health } \\
\text { Risk factors } \\
\text { Socioeconomic factors } \\
\text { Cultural characteristics Population groups }\end{array}$ \\
\hline & & $\mathrm{MeSH}$ & $\begin{array}{l}\text { Social determinants of health } \\
\text { Risk factors } \\
\text { Socioeconomic factors } \\
\text { Cultural characteristics } \\
\text { Population group }\end{array}$ \\
\hline & & CINAHL titles & $\begin{array}{l}\text { Social determinants of health } \\
\text { Risk factors } \\
\text { Socioeconomic factors } \\
\text { Population characteristics }\end{array}$ \\
\hline
\end{tabular}


The inclusion criteria were: articles (primary studies) that addressed the social determinants of health and the occurrence of suicide in the elderly population. Studies that addressed ideation and/or suicide attempt or that did not answer the research question were excluded. It is noteworthy that there was no time or language cut to select publications, for the objective was actually achieve a comprehensive approach.

The selection of works started by reading titles and abstracts, based on the inclusion criteria. Subsequently, a comprehensive analysis of the selected articles was performed and, to extract the data of interest, a validated form was used, with the following items: definition of subjects, methodology, sample size, measurement of variables, analysis method and supporting concepts employed. The level of evidence was classified as established by the Collaborating Center of the Joanna Briggs Institute (JBI)(9).

The studies were grouped according to the similarity between objectives, results, and conclusion; they were organized into thematic categories following the model proposed by Dahlgren and Whitehead ${ }^{(10)}$. The model shows that the SDHs are allocated in different layers, from a closer one, included in the individual determinants, to a more distant one, in which the macrodeterminants ${ }^{(6)}$ are found.

Thus, the theoretical categories listed were: proximal determinants, those related to the individual (age, sex, heredity and ethnic/racial conditions); intermediate determinants, which are allusive to lifestyle, social and community media; and distal determinants, which address living, working, and socioeconomic, cultural and environmental conditions in general ${ }^{(10)}$.

\section{RESULTS}

After reading titles and abstracts, 87 articles were obtained for full reading. Of these, 21 were considered potentially eligible. After analysis, 19 articles were included in the final sample of this integrative review (Figure 1), which followed Preferred Reporting Items for Systematic Reviews and Meta-Analyzes (PRISMA)'s recommendations.

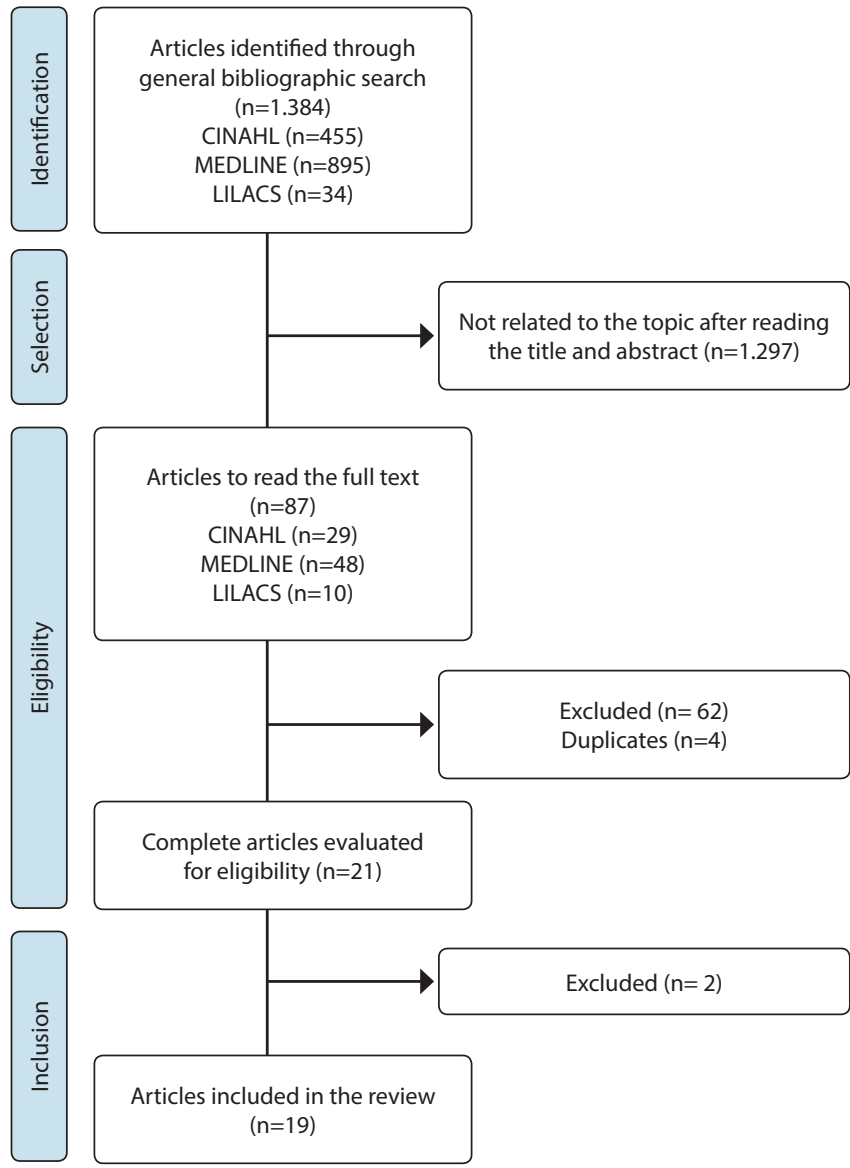

Figure 1 - Flowchart of study selection, Teresina, Piauí, Brazil, 2019

Chart 2 shows the characterization of all 19 articles used in this review. Regarding the study sites, most were carried out in the United States (USA). The years of publication vary between 1994 and 2019. As for the design, most were cross-sectional (12 studies), with a level of evidence III 3. The SDHs found in each study are distributed in the following chart:

Chart 2 - Characterization of selected studies according to authors, country, year of publication, study design, number of participants, objectives, social determinants of health, and level of evidence, Teresina, Piauí, Brazil, 2019

\begin{tabular}{|c|c|c|c|c|c|}
\hline Autors & $\begin{array}{l}\text { Country / Year } \\
\text { of publication }\end{array}$ & $\begin{array}{l}\text { Study outline } \\
\text { / Number of } \\
\text { participants }\end{array}$ & Objectives & $\begin{array}{l}\text { Social determinants of health } \\
\text { (SDH) }\end{array}$ & NE \\
\hline $\begin{array}{l}\text { Cavalcante FG, } \\
\text { Minayo MCS }\end{array}$ & Brazil / 2012 & $\begin{array}{l}\text { Descriptive study } \\
\text { with a qualitative } \\
\quad \text { approach } \\
\qquad \mathrm{N}=51\end{array}$ & $\begin{array}{l}\text { Performing at least } 50 \text { psychosocial } \\
\text { autopsies with relatives of elderly } \\
\text { who had died by suicide. That in ten } \\
\text { municipalities with high rates of these } \\
\text { events, spread through all five Brazilian } \\
\text { regions. }\end{array}$ & $\begin{array}{l}\text { Proximal SDHs: Male sex, physical } \\
\text { illnesses, and } \\
\text { mental disorders } \\
\text { Intermediate SDHs: Marital status, } \\
\text { social problems, previous suicide } \\
\text { attempt } \\
\text { Distal SDHs: Schooling, economic } \\
\text { issues }\end{array}$ & III 3 \\
\hline $\begin{array}{c}\text { Minayo MCS, } \\
\text { Cavalcante } \\
\text { FG }^{(12)}\end{array}$ & Brazil / 2013 & $\begin{array}{l}\text { Descriptive study } \\
\text { with a qualitative } \\
\text { approach } \\
\qquad \mathrm{N}=11\end{array}$ & $\begin{array}{l}\text { Empirically understanding } \\
\text { the cases and multiple causes of } 11 \\
\text { women who died by suicide and the } \\
\text { fragments of personal stories that led to } \\
\text { self-inflicted death, told by their families. }\end{array}$ & $\begin{array}{l}\text { Proximal SDHs: Physical illnesses } \\
\text { Intermediate SDHs: Violence and } \\
\text { family problems }\end{array}$ & III 3 \\
\hline
\end{tabular}




\begin{tabular}{|c|c|c|c|c|c|}
\hline Autors & $\begin{array}{l}\text { Country / Year } \\
\text { of publication }\end{array}$ & $\begin{array}{l}\text { Study outline } \\
\text { / Number of } \\
\text { participants }\end{array}$ & Objectives & $\begin{array}{l}\text { Social determinants of health } \\
\text { (SDH) }\end{array}$ & NE \\
\hline $\begin{array}{l}\text { Zurbarán GTG, } \\
\text { Rojo IG, } \\
\text { Acosta VAJ, } \\
\text { Jáuriga BL }{ }^{(13)}\end{array}$ & Cuba / 2001 & $\begin{array}{l}\text { Descriptive and } \\
\text { retrospective study } \\
\mathrm{N}=40\end{array}$ & $\begin{array}{l}\text { Observing epidemiological and } \\
\text { sociocultural variables in suicidal cases, } \\
\text { as well as suicidal behavior in the third } \\
\text { age and suicide methods found in } \\
\text { patients with depressive disorder and } \\
\text { disabling chronic disease. }\end{array}$ & $\begin{array}{l}\text { Proximal SDHs: Male sex, mental } \\
\text { disorder } \\
\text { Intermediate SDHs: Marital Status } \\
\text { Distal SDHs: } \\
\text { Economic issues }\end{array}$ & IV \\
\hline Shah $A^{(14)}$ & England / 2012 & $\begin{array}{l}\text { Cross-sectional, } \\
\text { correlational study } \\
\qquad \mathrm{N}=305\end{array}$ & $\begin{array}{l}\text { Examining the relationship between the } \\
\text { suicide rates of the elderly and indirect } \\
\text { measures of adversity in early life. }\end{array}$ & $\begin{array}{l}\text { Distal SDHs: } \\
\text { Sanitation }\end{array}$ & III 3 \\
\hline $\begin{array}{l}\text { Seyfried LS, } \\
\text { Kales HC, } \\
\text { Ignacio RV, } \\
\text { Conwell Y, } \\
\text { Valenstein } \mathrm{M}^{(15)}\end{array}$ & $\begin{array}{l}\text { United States / } \\
\qquad 2011\end{array}$ & $\begin{array}{l}\text { Retrospective cohort } \\
\text { study } \\
\mathrm{N}=294,952\end{array}$ & $\begin{array}{l}\text { Examining potential predictors of } \\
\text { suicide in the elderly, veteran patients } \\
\text { diagnosed with dementia. }\end{array}$ & $\begin{array}{l}\text { Proximal SDHs: White race and } \\
\text { mental disorders } \\
\text { Intermediate SDHs: Substance } \\
\text { abuse and use of psychotropic drugs }\end{array}$ & III 2 \\
\hline $\begin{array}{l}\text { Torresani S, } \\
\text { Toffol E, Scocco } \\
\text { P, Fanolla } A^{(16)}\end{array}$ & Italy / 2014 & $\begin{array}{l}\text { Cross-sectional and } \\
\text { retrospective study } \\
\qquad \mathrm{N}=525\end{array}$ & $\begin{array}{l}\text { Describing the characteristics of a } \\
\text { sample of elderly suicide victims in south } \\
\text { Tyrol (autonomous region in northern } \\
\text { Italy) and investigating whether the } \\
\text { characteristics and } \\
\text { risk factors for suicide of the elderly differ } \\
\text { according to different life settings at the } \\
\text { time of death. }\end{array}$ & $\begin{array}{l}\text { Proximal SDHs: Male sex and } \\
\text { mental disorders } \\
\text { Intermediate SDHs: } \\
\text { Marital Status } \\
\text { Distal SDHs: } \\
\text { Schooling, economic issues, stressful } \\
\text { life event (hospitalization) }\end{array}$ & III 3 \\
\hline $\begin{array}{l}\text { Wanta BT, } \\
\text { Schlotthauer } \\
\text { AE, Guse CE, } \\
\text { Hargarten } \\
\text { SW } \\
\text { S(17) }\end{array}$ & $\begin{array}{l}\text { United States / } \\
2009\end{array}$ & $\begin{array}{l}\text { Cross-sectional } \\
\text { study } \\
\mathrm{N}=534\end{array}$ & $\begin{array}{l}\text { Characterizing risk factors for } \\
\text { suicide in Wisconsin's elderly. }\end{array}$ & $\begin{array}{l}\text { Proximal SDHs: Male sex and } \\
\text { mental illnesses } \\
\text { Intermediate SDHs: Marital status } \\
\text { and alcohol consumption } \\
\text { Distal SDHs: } \\
\text { Schooling }\end{array}$ & III 3 \\
\hline $\begin{array}{l}\text { Grabbe L, Demi } \\
\text { A, Camann MA, } \\
\text { Potter } L^{(18)}\end{array}$ & $\begin{array}{l}\text { United States / } \\
1997\end{array}$ & $\begin{array}{l}\text { Cross-sectional and } \\
\text { retrospective study } \\
\qquad \mathrm{N}=9,181\end{array}$ & $\begin{array}{l}\text { Identifying health variables related } \\
\text { to suicide in } 65 \text {-year-old people and } \\
\text { older and comparing suicide with other } \\
\text { causes of death and health variables, } \\
\text { sociodemographic variables, daily life } \\
\text { activities, and the use of health services } \\
\text { during the later year of life. }\end{array}$ & $\begin{array}{l}\text { Proximal SDHs: Male, white race, } \\
\text { and mental disorders } \\
\text { Intermediate SDHs: Alcohol } \\
\text { consumption (three or more doses } \\
\text { per day), } \\
\text { previous suicide attempt } \\
\text { Distal SDHs: } \\
\text { Economic issues }\end{array}$ & III 3 \\
\hline $\begin{array}{l}\text { Almeida OP, } \\
\text { McCaul K, } \\
\text { Hankey GJ, } \\
\text { Yeap BB, } \\
\text { Golledge J, } \\
\text { Flicker L(19) }\end{array}$ & $\begin{array}{c}\text { Australia / } \\
2016\end{array}$ & $\begin{array}{l}\text { Cohort study } \\
\mathrm{N}=38,170\end{array}$ & $\begin{array}{l}\text { Investigating the prevalence and } \\
\text { incidence of suicide attempt among } \\
\text { Australian elderly and clarify how the } \\
\text { morbidity burden contributed to suicidal } \\
\text { behavior. }\end{array}$ & $\begin{array}{l}\text { Proximal SDHs: Mental disorders } \\
\text { and physical illnesses }\end{array}$ & III 2 \\
\hline $\begin{array}{l}\text { Altınöz AE, } \\
\text { Yenilmez C, } \\
\text { Öner SK, Yıldız } \\
\qquad P^{(20)}\end{array}$ & Turkey / 2019 & $\begin{array}{l}\text { Cross-sectional and } \\
\text { retrospective study } \\
\qquad \mathrm{N}=3,450\end{array}$ & $\begin{array}{l}\text { Comparing the causes and methods of } \\
\text { suicides among the elderly aged } 65 \text { to } \\
69,70 \text { to } 74 \text { and } \geq 75 \text {, for full rates of } \\
\text { gross suicide and sex between } 2002 \text { and } \\
2013 \text {. }\end{array}$ & $\begin{array}{l}\text { Proximal SDHs: Male, aged } 70 \text { to } 74 \\
\text { Intermediate SDHs: Marital } \\
\text { problems } \\
\text { Distal SDHs: } \\
\text { Economic issues }\end{array}$ & III 3 \\
\hline $\begin{array}{l}\text { Cheung G, } \\
\text { Merry S, } \\
\text { Sundram } \mathrm{F}^{(21)}\end{array}$ & $\begin{array}{l}\text { New Zealand / } \\
2018\end{array}$ & $\begin{array}{l}\text { Cross-sectional and } \\
\text { retrospective study } \\
\qquad \mathrm{N}=225\end{array}$ & $\begin{array}{l}\text { Reporting the characteristics of the } \\
\text { elderly who died by suicide and } \\
\text { investigate whether these characteristics } \\
\text { differ in three age groups: } 65-74,75-84 \text {, } \\
\text { and } 85 \text { or more. }\end{array}$ & $\begin{array}{l}\text { Intermediate SDHs: Marital } \\
\text { status, no history of admission to } \\
\text { psychiatric service }\end{array}$ & III 2 \\
\hline
\end{tabular}


Continuação do Quadro 2

\begin{tabular}{|c|c|c|c|c|c|}
\hline Autors & $\begin{array}{l}\text { Country / Year } \\
\text { of publication }\end{array}$ & $\begin{array}{l}\text { Study outline } \\
\text { / Number of } \\
\text { participants }\end{array}$ & Objectives & $\begin{array}{l}\text { Social determinants of health } \\
\text { (SDH) }\end{array}$ & NE \\
\hline $\begin{array}{l}\text { Cheung G, } \\
\text { Douwes G, } \\
\text { Sundram } \mathrm{F}^{(22)}\end{array}$ & $\begin{array}{c}\text { New Zealand / } \\
2017\end{array}$ & $\begin{array}{l}\text { Cross-sectional and } \\
\text { retrospective study } \\
\qquad \mathrm{N}=214\end{array}$ & $\begin{array}{l}\text { Comparing the sociodemographic and } \\
\text { clinical characteristics of elderly with and } \\
\text { without terminal cancer who died by } \\
\text { suicide and analyze the suicide reasons of } \\
\text { those with terminal cancer to determine } \\
\text { whether they represent rational suicide. }\end{array}$ & $\begin{array}{l}\text { Proximal SDHs: Male sex and } \\
\text { mental disorder } \\
\text { Intermediate SDHs: } \\
\text { Previous suicide attempt }\end{array}$ & III 2 \\
\hline $\begin{array}{l}\text { Ho RCM, Ho } \\
\text { ECL, Tai BC, Ng } \\
\text { WY, Chia BH(23) }\end{array}$ & $\begin{array}{c}\text { Singapore / } \\
2014\end{array}$ & $\begin{array}{l}\text { Cross-sectional } \\
\text { study } \\
\mathrm{N}=409\end{array}$ & $\begin{array}{l}\text { Identifying clinical predictor factors of } \\
\text { suicide in the elderly, especially those } \\
\text { without a history of suicidal behavior. }\end{array}$ & $\begin{array}{l}\text { Proximal SDHs: Mental disorder } \\
\text { Intermediate SDHs: Social } \\
\text { problems, alcohol consumption, use } \\
\text { of psychotropic drugs }\end{array}$ & III 2 \\
\hline $\begin{array}{l}\text { Carney SS, Rich } \\
\text { CL, Burke PA, } \\
\text { Fowler RC }\end{array}$ & $\begin{array}{l}\text { United States / } \\
1994\end{array}$ & $\begin{array}{l}\text { Cross-sectional } \\
\text { study } \\
\mathrm{N}=204\end{array}$ & $\begin{array}{l}\text { Verifying whether selected clinical } \\
\text { factors that characterize suicides after } \\
60 \text { years old differ from factors in } \\
\text { younger suicidal people and determine } \\
\text { characteristics of male and female } \\
\text { suicide in the elderly. }\end{array}$ & $\begin{array}{l}\text { Intermediate SDHs: Marital status } \\
\text { and previous suicide attempt } \\
\text { Distal SDHs: } \\
\text { Economic issues }\end{array}$ & III 3 \\
\hline $\begin{array}{c}\text { Préville } M \text {, } \\
\text { Hébert R, } \\
\text { Boyer R, Bravo } \\
\text { G, Seguin } \mathrm{M}^{(25)}\end{array}$ & Canada / 2005 & $\begin{array}{l}\text { Cross-sectional } \\
\text { study } \\
\mathrm{N}=95\end{array}$ & $\begin{array}{l}\text { Assessing the risk of suicide associated } \\
\text { with physical illness compared to elderly } \\
\text { people who died of natural causes. }\end{array}$ & Proximal SDHs: Mental disorders & III 3 \\
\hline $\begin{array}{l}\text { Zhou L, Wang } \\
\text { G, Jia C, Ma Z }\end{array}$ & China / 2018 & $\begin{array}{l}\text { Case-control study } \\
\qquad \mathrm{N}=242\end{array}$ & $\begin{array}{l}\text { Examining the relationship of } \\
\text { demographic characteristics, including } \\
\text { abandonment, mental disorder, } \\
\text { depressive symptoms, stressful life } \\
\text { events, social support and suicide. }\end{array}$ & $\begin{array}{l}\text { Proximal SDHs: Mental disorders } \\
\text { Intermediate SDHs: } \\
\text { Marital problems, alcohol } \\
\text { consumption and social problems } \\
\text { Distal SDH: } \\
\text { Stressful life events (unemployment, } \\
\text { hospitalization, and grief) }\end{array}$ & III 2 \\
\hline $\begin{array}{l}\text { Koo YW, Kõlves } \\
\text { K, Leo DD }\end{array}$ & $\begin{array}{c}\text { Australia / } \\
2017\end{array}$ & $\begin{array}{l}\text { Cross-sectional } \\
\text { study } \\
\mathrm{N}=978\end{array}$ & $\begin{array}{l}\text { Analyzing the differences in suicides } \\
\text { among the elderly ( } 65 \text { years old and } \\
\text { over) compared to middle-aged adults } \\
\text { (35-64 years old) in Queensland, } \\
\text { Australia, during the years } 2000 \text { to } 2012 \text {. }\end{array}$ & $\begin{array}{l}\text { Proximal SDHs: physical illnesses } \\
\text { Distal SDHs: Stressful life event } \\
\text { (grief) }\end{array}$ & \\
\hline $\begin{array}{l}\text { Sun WJ, Xu L, } \\
\text { Chan WM, Lam } \\
\text { TH, Schooling } \\
\text { CM }^{(28)}\end{array}$ & China / 2012 & $\begin{array}{l}\text { Cohort study } \\
N=55,946\end{array}$ & $\begin{array}{l}\text { Examining associations between } \\
\text { depressive symptoms and suicide and } \\
\text { modifiable factors such as sex, age and } \\
\text { health status in elderly Chinese }\end{array}$ & Proximal SDHs: Mental disorders & III 2 \\
\hline $\begin{array}{c}\text { Voshaar } \\
\text { RCO, Kapur } \\
\text { N, Bickley H, } \\
\text { Williams A, } \\
\text { Purandare N }{ }^{(29)}\end{array}$ & $\begin{array}{l}\text { England and } \\
\text { Wales }\end{array}$ & $\begin{array}{l}\text { Cross-sectional and } \\
\text { retrospective study } \\
\qquad \mathrm{N}=839\end{array}$ & $\begin{array}{l}\text { Comparing behavioral, clinical, and care } \\
\text { characteristics of elderly people with } \\
\text { early or late depression at the time of } \\
\text { suicide. }\end{array}$ & $\begin{array}{l}\text { Proximal SDHs: Male sex and } \\
\text { mental disorders } \\
\text { Intermediate SDHs: Marital status, } \\
\text { alcohol consumption and use of } \\
\text { psychotropic drugs }\end{array}$ & III 3 \\
\hline
\end{tabular}

\section{DISCUSSION}

\section{I - Proximal social determinants of health}

According to the Dahlgren and Whitehead model ${ }^{(10)}$, the individual is at the center; along with him are some characteristics, such as age, sex, and genetic factors, which influence his health ${ }^{(30)}$. Of the 19 articles analyzed by this study, 17 show a relationship between proximal SDHs and suicide in the elderly. The factors listed were: male gender ${ }^{(11,13,16-18,20,22,29)}$, presence of mental disor$\operatorname{ders}^{(11,13,15-19,22-23,25-26,28-29)}$, physical illnesses ${ }^{(11-12,19,27)}$, white race ${ }^{(15,18)}$ and age group from 70 to 74 years old ${ }^{(20)}$.
From a gender perspective, some studies that addressed suicide in the elderly population have demonstrated its association with males ${ }^{(11,13,16-19,22,29)}$. The literature indicates that, although women have higher rates of suicide attempts, men actually do so, being responsible for the highest number of suicides. This is mainly attributed to the methods used, which have a higher lethality level ${ }^{(31)}$. However, other explanations for this finding call into question the socially superior masculinity model as a vulnerability factor for suicide among elderly men, mostly due to the difficulty of performing cultural roles that are imposed ${ }^{(32)}$.

In third age, men tend to value stoicism, control of emotions, sexism, and competitiveness. The role of family head and provider, 
formerly belonging to the elderly, begins to be played by others, causing him to feel useless, incapable, and powerless. Leaving work because of retirement, chronic illnesses, financial problems, relationship problems, and changes in sexual performance are also potential aspects for suicidal behavior in the elderly ${ }^{(32)}$.

Another factor raised through the analysis of the articles was the presence of mental disorder ${ }^{(11,13,15-19,22-23,25-26,28-29)}$, the most mentioned disorder being depression and the others listed as bipolar disorder, anxiety and adjustment disorder. The presence of psychological disorder appears as an important vulnerabilizing aspect for suicide ${ }^{(33)}$. It is assumed that $90 \%$ of people who commit suicide have disorders of this sort ${ }^{(34)}$. However, depression occupies a prominent position, being considered the most common disorder in individuals who die by suicide ${ }^{(35)}$.

It is worth mention that the elderly are more resistant to show depressive symptoms or suicidal ideation. Thus, few receive diagnosis, and even fewer have access to treatment ${ }^{(36)}$. It is at this stage of life that depression shows its worse prognosis and a higher incidence of suicides ${ }^{(37)}$.

In addition to depression, other disorders are reported in literature as risk factors for self-inflicted death. A study conducted with 410 patients from a Psychosocial Care Center in Minas Gerais observed a statistically significant association between suicidal behavior and psychiatric comorbidity (psychotic or delusional disorders and maniac episode or bipolar affective disorder) among women. Men, in turn, presented a significant relationship between depression and psychiatric comorbidity (depression, schizophrenia, or disorders due to illicit drug use) and suicide ${ }^{(34)}$.

An integrative review with a time frame from 2002 to 2017, which evaluated ideation and suicide attempt in the elderly hospitalized in long-term care institutions, also mentions psychiatric problems as an important risk factor for the elderly population in general, highlighting depression, illicit substance abuse, personality disorders, behavioral disorder, previous history of suicide attempts, self-destructive indirect behaviors, direct harmful behaviors, cognitive impairment, and previous psychiatric diagnosis $^{(38)}$.

Another risk factor for self-inflicted violence observed among the studies was the presence of physical disease $\mathrm{P}^{(11-12,19,27)}$. A foreign study shows that the number of diseases increases the cumulative risk of suicide. Elderly people are six times more likely to acquire some physical disease when compared to young people, and are more vulnerable to multiple comorbidities, use of different medications and functional decline, aspects that make them even more prone to the risk of suicide ${ }^{(39)}$.

In the sociocultural panorama, the value of an individual corresponds to his productivity. The decrease in the functional capacity of elderly people can make them be seen as useless in some situations and awaken feelings of sadness and anguish. In addition, the elderly tend to self-judge as a hindrance, a situation that can be aggravated by the loss of autonomy and dependence on basic care ${ }^{(40)}$.

With regard to race, the white race was pointed out as a risk factor $^{(15,18)}$. Epidemiological studies that address this theme corroborate the finding and demonstrate that there is a higher occurrence of suicide in white than non-white people ${ }^{(41)}$. Research carried out at a national level found that, of the 164 cases of suicide attempt included, $46.3 \%$ were of the white race ${ }^{(42)}$.
The age group of 70 to 74 years old was also identified as more prone to suicide ${ }^{(20)}$. In a study on self-inflicted death in the elderly, carried out in the state of Piauí, the most prevalent age group was between 60 and 70 (54\% of the sample), followed by 71 to 80 (34.5\% of the sample). Statistical data also reveal that there is a tendency for the suicide rate to increase in the population aged between 70 and 80 years old ${ }^{(1)}$.

The analysis of the proximal SDHs considered in the present review reinforces the need to pay attention to individual characteristics in each elderly person, especially for the care established throughtout the territory, since these factors are intrinsic to the subject. Primary Health Care, in this context, can be taken as a differential device, which easily identifies such aspects and projects comprehensive assistance, including, beyond observing these SDHs, interventions toward risky behaviors.

\section{II - Intermediate social determinants of health}

In the second category, which addresses the middle layer of the SDHs, 14 articles referred to the following factors: substance abuse, alcohol consumption, use of psychotropic drugs, marital status, marital problems, social and family problems, violence, previous suicide attempt, and history of admission to psychiatric service.

Alcohol consumption is a public health problem among the elderly and was one of the main risk factors pointed out by multiple studies ${ }^{(15,17-18,23,26,29)}$. Added to substance abuse ${ }^{(15)}$, this practice exerts an irrefutable influence on the morbidity and mortality of this group. These harmful habits are intensified by the vulnerability of the elderly facing aging changes, loss of friends and family, loneliness, social isolation and financial difficulties ${ }^{(43)}$.

Besides, this practice has become uneventful and a habit adopted among men throughout their patch in life. This behavior generates anguish and guilt after consumption; it also exacerbates depressive effects and increasing impulsivity, reinforcing the probability of suicide. The consumption of alcohol and other substances may be a decisive aspect in the constitution of a suicidal experience. Therefore, it should not be investigated in isolation, but as a clear social factor when discerning suicide ${ }^{(26,44)}$.

In the case surveys conducted ${ }^{(15,23,29)}$, significant associations were detected between the use of psychotropic drugs and suicide in the elderly. This fact is attributed to the frequent presence of psychiatric comorbidities in this population, which is an important risk factor, in addition to the use of psychotropic drugs to relieve somatic dysfunctions ${ }^{(15)}$.

Also, studies indicate an association between marital status and suicide, where married individuals prevail ${ }^{(11,16,21,24,29)}$. This phenomenon can be explained by the fact that relationships of elderly couples are often instituted in youth, conserved for years and kept during all the transitions of life, until old age ${ }^{(45)}$. However, long-lasting relationships can refer to marital problems, considered an important determinant for suicide in the elderly ${ }^{(20,26)}$. These marital issues involve problems with sexuality, loss of control over the relationship and feeling of failure in exercising the male role according to the patriarchal culture, which predisposes such male individuals to suicidal outcomes ${ }^{(46)}$.

Another condition related to suicide in the elderly were social problems $^{(11,23,26)}$ and family members ${ }^{(12)}$; it reflects the impoverishment 
of primary relationships when it comes to routine dynamics, making intolerable the sphere of coexistence. Besides, social disconnection generates potentially negative repercussions on their mental health, and because they feel unsupported and mostly emotionally unsupported, the elderly release themselves from the link with life and intend to anticipate its end ${ }^{(47)}$. It is noteworthy that these family and social conflicts predispose to violence - another determinant associated with suicide, which, without mediation, interferes in personal relationships, nourishes traumas and raises suicidal ideas ${ }^{(12)}$.

In this population, there is a close relationship between ideation, attempted and consummated suicide. Among the elderly, approximately two to four attempts are made before the suicide itself ${ }^{(48)}$. Thus, the presence of ideation or attempts intensifies the risk of self-inflicted deaths, a fact confirmed by some authors ${ }^{(11,18,22,24)}$; it should thus be approached in greater depth, for it is directly related to consummated suicide and is a warning for possible later practice.

Also, regarding intermediate SDHs, another factor associated with suicide in the elderly was the absence of previous admissions to psychiatric service ${ }^{(21)}$, which exposes the neglect of the family or the elderly regarding the treatment of mental disorders - factors that may drive suicide -, apart from the difficulty of attending the services. The places should seek strategies that bring the elderly closer to programs aimed at a specific care for this public. This would surely solve the difficulties and promote prevention ${ }^{(11)}$.

With information on intermediate SDHs that have an impact on self-inflicted death in the elderly, we note the importance of redirecting policies that favor good development conditions for individuals, focusing on health conditions, life habits, social ties and networks of support. In addition to health care, psychosocial attention must be given to building community bases, which interact in the entire individual's process of development and influence the well-being of the elderly population.

\section{III - Distal social determinants of health}

In the third category, ten studies mentioned distal SDHs such as schooling ${ }^{(11,16)}$, economic issues ${ }^{(11,13,16,18,20,24)}$, sanitation ${ }^{(14)}$, and stressful life events ${ }^{(16,26-27)}$.

Factors such as social inequality, low income, financial failure, and schooling influence the occurrence of suicide. A probable explanation is that social and economic conditions drive different material life models, with varying degrees of exposure to environmental risk factors and access to resources. This causes changes in behavioral and psychosocial aspects, such as perception of violence, feelings of deprivation, and stress. Thus, economic factors and low education level influence the individual's health, including his mental health ${ }^{(4)}$.
The mention of these aspects refers to a deficit in social support, which consists in the failure of governments to minimize stressful events related to the social environment. These stressors are usually basic sanitation, housing characteristics, and job opportunities ${ }^{(49)}$.

Another stressor is the grieving process, found in the bibliographic analysis as a risk factor for suicide in the elderly ${ }^{(12-27)}$. The sense of loss is traumatic and may never go away completely. In some cases, it can evolve negatively, causing physical and psychological problems, which include substance abuse and psychiatric disorders, until the suicidal outcome ${ }^{(50)}$.

The identified economic, social and cultural macrodeterminants denote a context that includes stratification mechanisms, defining the individual socioeconomic hierarchy and weakening access to resources. This also means that individuals at a social disadvantage are subject to different risks. Through integrated intersectoral policies, measures that address the essential needs and rights of the population in the various contexts of State action will contribute to a healthy aging.

\section{Study limitations}

It is emphasized as a limitation of the present study the noninclusion of other databases, since other articles that were not indexed in the bases of choice could not be selected to constitute the sample.

\section{Contributions to the fields of Nursing, Health, or Public policy}

Deepening and recognizing the SDHs related to suicide in the elderly is fundamental both for the adherence of preventive measures, essentially of modifiable factors, and for the definition of health policies that provide resolutive care, with the valorization of the elderly in a perspective of integrality. The relevance of investing in risk reduction is emphasized; it is considered the network of social and cultural factors in which individuals are inserted.

\section{CONCLUSION}

It was observed that proximal determinants have more effects on the practice of suicide, especially mental disorders, with emphasis on depression. In addition, physical problems were also listed as predisposing factors to the occurrence of suicide. As for Intermediate determinants, they are mainly composed of modifiable factors and subject to interventions, since they are listed as alcohol use, substance abuse, family, marital, and social problems. Now as for Distal determinants, lower associations were found, and these SDHs' mechanisms of action were not recognized as presuming suicide in the elderly.

\section{REFERENCES}

1. Gomes AV, Cardoso PKB, Rocha FCV, Carvalho CMS, Sales MCV. Sociodemographic profile of elderly suicide victims in a northeastern state of Brazil. Rev Baiana Enferm. 2018;32:e26078. doi: 10.18471/rbe.v32.26078

2. Amudhan S, Gururaj G, Varghese M, Benegal V, Rao GN, Sheehan DV et al. A population-based analysis of suicidality and its correlates: findings from the National Mental Health Survey of India, 2015-16. Lancet Psychiatry. 2020;7(1):41-51. doi: 10.1016/S2215-0366(19)30404-3 
3. World Health Organization (WHO). Preventing suicide: a global imperative [Internet]. 2014 [cited 2019 Jun 13]. Available from: http://www. who.int/mental_health/suicide-prevention/world_report_2014/en/

4. Santos EGO, Oliveira YOMC, Azevedo UN, Nunes ADS, Amador AE, Barbosa IR. Spatial temporal analysis of mortality by suicide among the elderly in Brazil. Rev Bras Geriatr Gerontol. 2018;20(6):854-65. doi: 10.1590/1981-22562017020.170115

5. Carvalho ILN, Lôbo APA, Aguiar CAA, Campos AR. Suicidally motivated intoxication by psychoactive drugs: characterization among the elderly. Rev Bras Geriatr Gerontol. 2017;20(1):129-37. doi: 10.1590/1981-22562017020.160064

6. Garbois JA, Sodré F, Dalbello-Araujo M. Da noção de determinação social à de determinantes sociais da saúde. Saúde Debate. 2017;41(112):63-76. doi: 10.1590/0103-1104201711206

7. Ganong LH. Integrative reviews of nursing research. Res Nurs Health. 1987;10(1):1-11. doi: 10.1002/nur.4770100103

8. Lockwood C, Porrit K, Munn Z, Rittenmeyer L, Salmond S, Bjerrum M, et al. Chapter 2: Systematic reviews of qualitative evidence [Internet]. In: Aromataris E, Munn Z, editors. Joanna Briggs Institute, 2017 [cited 2019 May 12]. Available from: https://reviewersmanual.joannabriggs. org

9. Institute Joanna Briggs. Joanna Briggs Institute Reviewers' Manual: 2014 Edition. [Internet]. Adelaide: Joanna Briggs Institute; 2014 [cited 2019 May 12]. Available from: http://joannabriggs.org/assets/docs/sumari/ReviewersManual-2014.pdf

10. Dahlgren G, Whitehead M. Policies and strategies to promote social equity in health. Background document to WHO - Strategy paper for Europe. Stockolm: Arbetsrapport/ Institutet for Framtidsstudier [Internet]. 2007 [cited 2019 May 12];14:01-69. Available from: http://www. iffs.se/media/1326/20080109110739filmZ8UVQv2wQFShMRF6cuT.pdf

11. Cavalcante FG, Minayo MCS. Autópsias psicológicas e psicossociais de idosos que morreram por suicídio no Brasil. Ciênc Saúde Colet. 2012;17(8):1943-54. doi:10.1590/S1413-81232012000800002

12. Minayo MCS, Cavalcante FG. Estudo compreensivo sobre suicídio de mulheres idosas de sete cidades brasileiras. Cad Saude Publica. 2013;29(12):2405-15. doi: 10.1590/0102-311X00048013

13. Zurbarán GTT, Rojo IG, Acosta VAJ, Jáuriga BL. Suicidio en la tercera edad: un problema de salud comunitario. Rev Cubana Hig Epidemiol [Internet]. 2001 [cited 2019 Jul 08];39(2):147-51. Avaliable from: http://scielo.sld.cu/scielo. php?script=sci_arttext\&pid=S1561-30032001000200012\&lng=es

14. Shah A. A replication of the relationship between adversity earlier in life and elderly suicide rates using five years cross-national data. J Inj Violence Res. 2012;4(1):7-9. doi: 10.5249/jivr.v4i1.65

15. Seyfried LS, Kales HC, Ignacio RV, Conwell Y, Valenstein M. Predictors of suicide in patients with dementia. Alzheimers Dement. 2011;7(6):567-73. doi: 10.1016/j.jalz.2011.01.006

16. Torresani S, Toffol E, Scocco P, Fanolla A. Suicide in elderly South Tyroleans in various residential settings at the time of death: a psychological autopsy study. Psychogeriatrics. 2014;14(2):101-9. doi: 10.1111/psyg.12046

17. Wanta BT, Schlotthauer AE, Guse CE, Hargarten SW. The burden of suicide in Wisconsin's older adult population. WMJ [Internet]. 2009 [cited 2019 July 05];108(2):87-93. Available from: https://www.ncbi.nlm.nih.gov/pubmed/19437934

18. Grabbe L, Demi A, Camann MA, Potter L. The health status of elderly persons in the last year of life: a comparison of deaths by suicide, injury, and natural causes. Am J Public Health. 1997;87(3):434-7. doi: 10.2105/ajph.87.3.434

19. Almeida OP, McCaul K, Hankey GJ, Yeap BB, Golledge J, Flicker L. Suicide in older men: the health in men cohort study (HIMS). Prev Med. 2016;93:33-8. doi: 10.1016/j.ypmed.2016.09.022

20. Altınöz AE, Yenilmez Ç, Öner SK, Yıldız P. Completed suicide rates of older adults in 5-year age bands in Turkey between 2002 and 2013 : a retrospective study. Geriatr Gerontol Int. 2019;19(1):66-9. doi: 10.1111/ggi.13569

21. Cheung G, Merry S, Sundram F. Do suicide characteristics differ by age in older people? Int Psychogeriatr. 2018;30(3):323-30. doi: 10.1017/ S1041610217001223

22. Cheung G, Douwes G, Sundram F. Late-Life suicide in terminal cancer: a rational act or underdiagnosed depression? J Pain Symptom Manage. 2017;54(6):835-42. doi: 10.1016/j.jpainsymman.2017.05.004

23. Ho RCM, Ho ECL, Tai BC, Ng Wl, Chia BH. Elderly suicide with and without a history of suicidal behavior: implications for suicide prevention and management. Arch Suicide Res. 2014;18(4):363-75. doi: 10.1080/13811118.2013.826153

24. Carney SS, Rich CL, Burke PA, Fowler RC. Suicide over 60: the San Diego study. J Am Geriatr Soc. 1994;42(2):174-80. doi: 10.1111/j.15325415.1994.tb04948.x

25. Préville M, Hébert R, Boyer R, Bravo G, Seguin M. Physical health and mental disorder in elderly suicide: a case-control study. Aging Ment Health. 2005;9(6):576-84. doi: 10.1080/13607860500192973

26. Zhou L, Wang G, Jia C, Ma Z. Being left-behind, mental disorder, and elderly suicide in rural China: a case-control psychological autopsy study. Psychol Med. 2018;49(3):458-64. doi: 10.1017/S003329171800106X

27. Koo YW, Kõlves K, Leo DD. Suicide in older adults: differences between the young-old, middle-old, and oldest old. Int Psychogeriatr. 2017;29(8):1297-306. doi: 10.1017/S1041610217000618

28. Sun WJ, Xu L, Chan WM, Lam TH, Schooling CM. Depressive symptoms and suicide in 56,000 older Chinese: a Hong Kong cohort study. Soc Psychiatry Psychiatr Epidemiol. 2012;47(4):505-14. doi: 10.1007/s00127-011-0362-z 
29. Voshaar RC, Kapur N, Bickley H, Williams A, Purandare N. Suicide in later life: a comparison between cases with early-onset and late-onset depression. J Affect Disord. 2011;132(1-2):185-91. doi:10.1016/j.jad.2011.02.008

30. Carrapato P, Correia P, Garcia B. Determinante da saúde no Brasil: a procura da equidade na saúde. Saúde Soc. 2017;26(3):676-89. doi: 10.1590/s0104-12902017170304

31. Rosa NM, Agnolo CMD, Oliveira RR, Mathias TAF, Oliveira MLF. Tentativas de suicídio e suicídios na atenção pré-hospitalar. J Bras Psiquiatr. 2016;65(3):231-38. doi: 10.1590/0047-2085000000129

32. Minayo MCS, Meneghel SN, Cavalcante FG. Suicide of elderly men in Brazil. Cien Saude Colet. 2012;17(10):2665-74. doi: 10.1590/ S1413-81232012001000016

33. Choo CC, Chew PKH, Ho RC. Controlling noncommunicable diseases in transitional economies: mental illness in suicide attempters in Singapore-an exploratory analysis. Biomed Res Int. 2019;15(2019):4652846. doi: 10.1155/2019/4652846

34. Botti NCL, Leal MCC, Marques AO, Vieira JCM. Characteristics and risk factors for suicidal behavior among men and women with psychiatric disorders. Cogitare Enferm. 2018;23(2):e54280. doi: 10.5380/ce.v23i1.54280

35. Ahmed HU, Hossain MD, Aftab A, Soron TR, Alam MT, Chowdhury MWA et al. Suicide and depression in the World Health Organization South-East Asia Region: a systematic review. WHO South East Asia J Public Health. 2017;6(1):60-66. doi: 10.4103/2224-3151.206167

36. Cavalcante FG, Minayo MCS, Mangas RMN. Diferentes faces da depressão no suicídio em idosos. Cien Saude Colet. 2013;18(10):2985-94. doi: $10.1590 /$ S1413-81232013001000023

37. Brooks SE, Burruss SK, Mukherjee K. Suicide in the elderly: a multidisciplinary approach to prevention. Clin Geriatr Med. 2018;35(1):133-145. doi: 10.1016/j.cger.2018.08.012

38. Minayo MCS, Figueiredo AEB, Mangas RMN. Study of scientific publications (2002-2017) on suicidal ideation, suicide attempts and self-neglect of elderly people hospitalized in Long-Term Care Establishments. Cien Saude Colet. 2019;24(4):1393-404. doi: $10.1590 / 1413-81232018244.01422019$

39. Conwell Y, Thompson C. Suicidal Behavior in Elders. Psychiatr Clin North Am. 2008;31(2):333-56. doi: 10.1016/j.psc.2008.01.004

40. Gutierrez DMD, Sousa ABL, Grubits S. Suicidal ideation and attempted suicide in elderly people: subjective experiences. Cien Saude Colet. 2015;20(6):1731-40. doi: 10.1590/1413-81232015206.02242015

41. Schmutte T, Olfson M, Xie M, Marcus SC. National study of emergency department disposition for high suicide risk geriatric patients. Gen Hosp Psychiatry. 2019;58:67-70. doi: 10.1016/j.genhosppsych.2019.03.005

42. Vieira LP, Santana VTP, Suchara EA. Caracterização de tentativas de suicídios por substâncias exógenas. Cad Saude Colet. 2015;23(2):118-23. doi: 10.1590/1414-462X201500010074

43. Costa IP, Oliveira FKS, Pimenta CJL, Almeida MR, Moraes JCO, Costa SP. Aspectos relacionados ao abuso e dependência de álcool por idosos. Rev enferm UFPE on line. 2017;11(6):2323-28. doi: 10.5205/reuol.10827-96111-1-ED.1106201710

44. Ribeiro DB, Terra MG, Soccol KLS, Schneider JF, Camillo LA, Plein FAS. Reasons for attempting suicide among men who use alcohol and other drugs. Rev Gaucha Enferm. 2016;37(1):e54896. doi: 10.1590/1983-1447.2016.01.54896

45. Silva EP, Nogueira IS, Labegalini CMG, Carreira L, Baldissera VDA. Perceptions of care among elderly couples. Rev Bras Geriatr Gerontol. 2019;22(1):e180136. doi: 10.1590/1981-22562019022.180136

46. Sousa GS, Silva RM, Figueiredo AEB, Minayo MCS, Vieira LJES. Circunstâncias que envolvem o suicídio de pessoas idosas. Interface Comun Saúde Educ. 2014;18(49):389-402. doi: 10.1590/1807-57622013.0241

47. Silva RM, Mangas RMN, Figueiredo AEB, Vieira LJES, Sousa GS, Cavalcanti AMTS, et al. The influence of family problems and conflicts on suicidal ideation and suicide attempts in elderly people. Cien Saude Colet. 2015;20(6):1703-10. doi: 10.1590/1413-81232015206.01952015

48. Minayo MCS, Cavalcante FG. Suicide attempts among the elderly: a review of the literature (2002/2013). Cien Saude Colet. 2015;20(6):175162. doi: 10.1590/1413-81232015206.10962014

49. Oliveira EN, Félix TA, Mendonça CBL, Lima PSF, Freire AS, Moreira RMM. Aspectos epidemiológicos e o cuidado de enfermagem na tentativa de suicídio. Rev Enferm Contemp. 2016;5(2):184-92. doi: 10.17267/2317-3378rec.v5i2.967

50. Sousa GS, Perrelli JGA, Mangueira SO, Sougey EB. Validation by experts of Risk of suicide Nursing Diagnosis in the elderly. Rev Bras Enferm. 2019;72(Suppl 2):111-18. doi: 10.1590/0034-7167-2018-0252 